Thiago Saads CARVALHO(a) Bianca Glerean PETERS(b) Daniela RIOS(c)

Ana Carolina MAGALHÃES(d) Fabio Correia SAMPAIO(e)

Marília Afonso Rabelo BUZALAF ${ }^{(\mathrm{d})}$ Marcelo José Strazzeri BÖNECKER(b)

(a) University of Bern - Unibe, School of Dental Medicine, Department of Preventive, Restorative and Pediatric Dentistry, Bern, Switzerland.

(b) Universidade de São Paulo - USP, School of Dentistry, Department of Pediatric Dentistry, São Paulo, SP, Brazil.

(c) Universidade de São Paulo - USP, Bauru School of Dentistry, Department of Pediatric Dentistry, Orthodontics and Community Health, Bauru, SP, Brazil.

(d) Universidade de São Paulo - USP, Bauru School of Dentistry, Department of Biological Sciences, Bauru, SP, Brazil.

(e) Universidade Federal da Paraíba - UFP Health Science Center, Laboratório de Biologia Bucal, João Pessoa, PB, Brazil.

Declaration of Interests: The authors certify that they have no commercial or associative interest that represents a conflict of interest in connection with the manuscript.

Corresponding Author:

Thiago Saads Carvalho

Email: thiagosaads@hotmail.com

DOI: 10.1590/1807-3107BOR-2015.vol29.0092

Submitted: Dec 11, 2014

Accepted for publication: Feb 27, 2015

Last revision: Jun 18, 2015

\section{Fluoride varnishes with calcium glycerophosphate: fluoride release and effect on in vitro enamel demineralization}

Abstract: The aims of this study were (1) to assess the amount of fluoride (F) released from varnishes containing calcium glycerophosphate $(\mathrm{CaGP})$ and (2) to assess the effect of the experimental varnishes on in vitro demineralization. Six test groups using 5 varnishes: base varnish (no active ingredients); Duraphat ${ }^{\circledR}(2.26 \% \mathrm{NaF}) ;$ Duofluorid $^{\circledR}$ (5.63\% NaF/ $\left.\mathrm{CaF}_{2}\right)$; experimental varnish 1 (1\% CaGP/5.63\% NaF/CaF $)_{2}$; experimental varnish 2 (5\% CaGP/5.63\% $\left.\mathrm{NaF} / \mathrm{CaF}_{2}\right)$; and no varnish were set up. In stage 1, 60 acrylic blocks were randomly distributed into 6 groups $(\mathrm{n}=10)$. Then $300 \mu \mathrm{g}$ of each varnish was applied to each block. The blocks were immersed in deionized water, which was changed after 1, 8, 12, 24, 48 and 72 hours. Fluoride concentration in the water was analyzed using a fluoride electrode. In stage 2, 60 bovine enamel samples were distributed into 6 groups $(\mathrm{n}=10)$, and treated with $300 \mu \mathrm{g}$ of the respective varnish. After $6 \mathrm{~h}$ the varnish was removed and the samples were subjected to a 7-day in vitro $\mathrm{pH}$ cycle ( $6 \mathrm{~h}$ demineralization/18 $\mathrm{h}$ remineralization per day). The demineralization was measured using surface hardness. The results showed that both experimental varnishes released more fluoride than Duofluorid $^{\circledR}$ and Duraphat ${ }^{\circledR}(p<0.05)$, but Duraphat ${ }^{\circledR}$ showed the best preventive effect by decreasing enamel hardness loss $(p<0.05)$. Therefore, we conclude that even though (1) the experimental varnishes containing CaGP released greater amounts of F, (2) they did not increase in the preventive effect against enamel demineralization.

Keywords: Fluorides, Topical; Glycerophosphates; Dental Enamel; Dental Caries.

\section{Introduction}

Dental caries occurs when the presence of acids on the tooth-plaque interface leads to a shift in the demineralization/remineralization equilibrium favoring a net demineralization of the enamel. ${ }^{1,2}$ The decline seen in the prevalence of dental caries is mostly related to the use of topical fluoride (F) present in dental products. ${ }^{3}$ Several dental products are available for the prevention and treatment of initial caries lesions.

It is generally accepted that, when they come into contact with the dental enamel, $\mathrm{F}$ agents promote the precipitation of a calcium fluoride-like 
$\left(\mathrm{CaF}_{2}\right.$-like) layer, which serves as a mineral reservoir of $\mathrm{F}$ and calcium in the mouth. The $\mathrm{F}$ and calcium released from the $\mathrm{CaF}_{2}$-like layer during cariogenic challenges can reduce demineralization. ${ }^{4}$ Agents containing calcium glycerophosphate (CaGP) have also shown protective effects against cariogenic demineralization, ${ }^{5,6,7}$ since CaGP interacts with hydroxyapatite increasing its resistance, ${ }^{8}$ exhibiting a cumulative effect together with $\mathrm{F} .{ }^{9}$ When present in dentifrices, CaGP has been shown to increase the caries-preventive effect, ${ }^{5,6,7,10}$ but conflicting results have also been reported. ${ }^{11}$

The high $\mathrm{F}$ concentration in varnishes also has a positive effect on caries prevention. ${ }^{12}$ because substantial amounts of $\mathrm{CaF}_{2}$-like material can form on enamel. ${ }^{13,14,15,16,17}$ On the other hand, conflicting results have been reported with respect to the application of F varnish for caries control as part of routine clinical practice. ${ }^{18,19}$ Further studies on the improvements resulting from $F$ varnishes are therefore needed. This study aimed at (1) assessing the amount of $F$ released from the F varnishes containing CaGP, and (2) assessing the effect of experimental varnishes on enamel demineralization.

\section{Methodology}

This study was divided into two stages. Both stages involved 5 varnishes:

i. base varnish (no active ingredients); FGM, Joinville, Brazil;

ii. Duraphat ${ }^{\circledR}\left(2.26 \% \mathrm{~F}^{-}\right.$as $\left.\mathrm{NaF}\right)$; Colgate-Palmolive $\mathrm{GmbH}$, Hamburg, Germany;

iii. Duofluorid ${ }^{\circledast}\left(2.71 \% \mathrm{~F}^{-}\right.$as $\mathrm{NaF}$ and $2.92 \% \mathrm{~F}^{-}$as $\mathrm{CaF}_{2}$ [total 5.63\% F-]); FGM, Joinville, Brazil;

iv. experimental varnish 1 ( $1 \%$ CaGP and $\left.5.63 \% \mathrm{~F}^{-}\right)$; FGM, Joinville, Brazil;

v. experimental varnish 2 (5\% CaGP and $\left.5.63 \% \mathrm{~F}^{-}\right)$; FGM, Joinville, Brazil.

The base varnish, Duofluorid ${ }^{\circledR}$ and experimental varnishes 1 and 2 were provided by the same manufacturer. These whitish varnishes contain synthetic resins and they are less viscous than Duraphat $t^{\circledast}$. Duraphat ${ }^{\circledR}$ contains colophonium, shellac, mastic resin and white wax, and it is a yellowish-orange viscous resin.

\section{Fluoride release from the varnishes}

Sixty acrylic blocks $(10 \times 10 \times 1 \mathrm{~mm})$ were distributed into 6 groups $(\mathrm{n}=10)$ : group 1 - base varnish, group 2 - Duraphat ${ }^{\circledR}$, group 3 - Duofluorid ${ }^{\circledR}$, group 4 - experimental varnish 1 , group 5 - experimental varnish 2 and group 6 - control group with no varnish application. Using a precision scale, $300 \mu \mathrm{g}$ of the respective varnish was applied to each acrylic block in groups 1-5. No varnish was applied to the blocks in group 6, which served as the control. The blocks were then placed into plastic vials containing $10 \mathrm{ml}$ of distilled deionized water (DDW). The blocks remained immersed in the DDW for $1 \mathrm{~h}$ under still conditions, at room temperature. After this time, the acrylic blocks were removed from the first vial and placed into a new vial containing a fresh $10-\mathrm{mL}$ aliquot of DDW. The acrylic blocks were again placed into new vials containing fresh DDW after 1, 8, 12, 24, 48 and 72 hours. The amount of F released to the DDW was analyzed using a fluoride-sensitive electrode (F electrode, Thermo Orion), adapted with a reference electrode and connected to a millivoltage reader (Thermo Orion). The electrode had been calibrated with standard solutions of known F concentrations: $0.15,0.3,0.6,1.3,2.5,5.0,10.0,20.0,40.0$ and $80.0 \mu \mathrm{g} / \mathrm{mL}$, containing standard total ionic strength adjustment buffer solution (TISAB III). A new calibration was performed before the reading of each group of 10 samples and the coefficient of variation of the electrode throughout the whole experiment was $5.39 \%$. The samples were read in duplicate, and the mean of the two readings was calculated and recorded as the concentration of $\mathrm{F}$ in the sample $(\mu \mathrm{g} / \mathrm{mL})$.

\section{Effect of the experimental varnishes on enamel demineralization}

Sixty bovine incisors were cut (Isomet, Buehler Ltd., Evanston, USA) to obtain 60 enamel samples $(4 \times 4 \times 2 \mathrm{~mm})$. The enamel samples were ground and serially polished using 600, 1200 and 2400 grit papers (ANSI grit; Buehler, Lake Bluff, USA), to obtain flat polished surfaces. Initial enamel surface microhardness was measured using a microhardness tester with a Knoop diamond indenter (HMV-2000; Shimadzu Corp., Tokyo, Japan). Five sequential indentations were made, $100 \mu \mathrm{m}$ apart, using a $50 \mathrm{~g}$ 
load for 5 seconds. The initial Knoop hardness number $\left(\mathrm{KNH}_{\text {initial }}\right)$ for each enamel sample corresponded to the average of the five indentations. The enamel samples were randomly divided into 6 groups $(n=10)$, for treatment with the abovementioned varnishes. Half of each enamel sample surface was covered with a layer of nail varnish to maintain a control surface (untreated surface). The other half was covered with $300 \mu \mathrm{g}$ of the test varnish. The samples were then individually placed in $30 \mathrm{~mL}$ demineralizing solution $\left(2.0 \mathrm{mM} \mathrm{CaCl}_{2}, 2.0 \mathrm{mM} \mathrm{NaH}_{2} \mathrm{PO}_{4} ; 0.075 \mathrm{mM}\right.$ acetate buffer, $0.02 \mathrm{ppm} \mathrm{F,} \mathrm{pH} \mathrm{4.7)} \mathrm{for} 6 \mathrm{~h}$ at $37^{\circ} \mathrm{C} .{ }^{20}$ The varnish layer was then carefully removed from the enamel surface using a cotton pellet soaked in acetone (1:1 dilution with DDW) and a scalpel blade, taking care not to touch the enamel surface and leaving the other half covered with a layer of nail varnish. Each sample were then individually placed in $15 \mathrm{~mL}$ remineralizing solution $\left(1.5 \mathrm{mM} \mathrm{CaCl}_{2}\right.$, $0.9 \mathrm{mM} \mathrm{NaH}_{2} \mathrm{PO}_{4}, 150 \mathrm{mM} \mathrm{KCl}, 0.1 \mathrm{M}$ Tris buffer, 0.03 ppm F, pH 7.0) $)^{20}$ for $18 \mathrm{~h}$ at $37^{\circ} \mathrm{C}$.

In total, the samples underwent a 7-day $\mathrm{pH}$ cycle of $6 \mathrm{~h}$ demineralization and $18 \mathrm{~h}$ remineralization per day, without stirring. Between each step, the samples were washed in running DDW. The solutions were changed daily, and during the last 2 days of the experiment the samples were immersed in remineralizing solution only. At the end of the experiment, final enamel surface hardness was again measured following the same process as previously described. The percentage of surface hardness change for each sample was calculated using the formula: $\% \mathrm{SHC}=100 *\left(\mathrm{KNH}_{\text {final }}-\mathrm{KNH}_{\text {initial }}\right) / \mathrm{KNH}_{\text {initial }}$.

\section{Statistical analyses}

In stage 1, the F measurements were taken after different lengths of time; therefore, the area under the curve (AUC) was calculated for each time interval $\left(\left[t_{2}-t_{1}\right]^{*}\left[F_{2}+F_{1}\right] / 2\right.$; where $t$ is the time and $F$ is the fluoride measurement), as well as the total AUC for the whole experiment. Normality and homogeneity of variance were analyzed using the Shapiro-Wilk and Levine tests, respectively. Repeated measures ANOVA analysis and Tukey's post-hoc test were then carried out using the AUC values as the dependent variable to verify differences between the groups.

For stage 2, the effects of the different varnishes on artificial caries were checked using ANOVA and post-hoc Tukey's tests using the mean values for \%SHC.

\section{Results}

Figure 1 shows the concentration of F released by each varnish to the DDW, and the respective AUC is presented in Table1. The base varnish and the negative control group released similar amounts of $\mathrm{F}$ and their lines on the graph trace the same trajectory (Figur 1). The base varnish and negative control released significantly less $\mathrm{F}$ than the other test materials $(\mathrm{p}<0.05)$. In respect to the $F$ varnishes, Duraphat ${ }^{\circledR}$ released the least amount of $F$ than the other $F$ varnishes (e.g. Duraphat ${ }^{\circledR}$ released about $70 \%$ less $F$ than Duofluorid ${ }^{\circledR}$ ). However, Duofluorid $^{\circledR}$ released significantly less $F$ than the experimental varnishes containing CaGP $(p<0.05)$. Both experimental varnishes released significantly more $\mathrm{F}$ than the commercially available varnishes. Moreover, experimental varnish 1 , which contained $1 \%$ CaGP, released the greatest amount of $F(p<0.05)$.

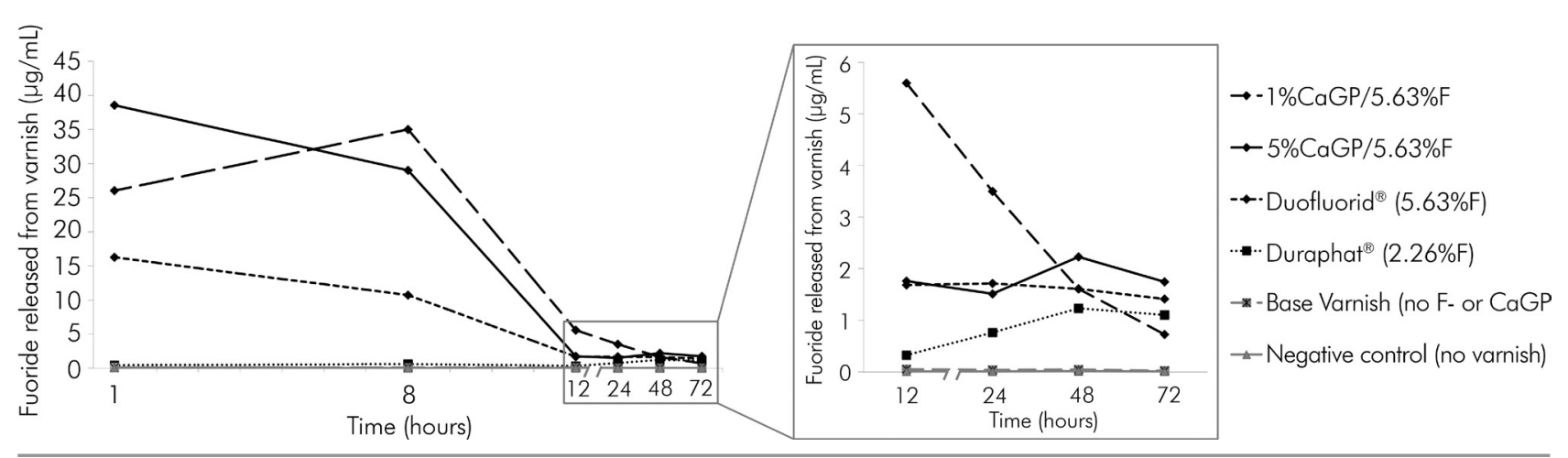

Figure 1. The amount of fluoride released from each varnish throughout the 72 hours of the experiment. 
Table 1. Mean cumulative $\pm S D$ values for the area under the curve (AUC) for fluoride release from each group.

\begin{tabular}{|c|c|c|c|c|c|c|}
\hline \multirow{2}{*}{ Varnish } & \multicolumn{5}{|c|}{ Mean $( \pm S D)$ AUC values for the time periods between } & \multirow{2}{*}{ AUC total } \\
\hline & 1 and $8 \mathrm{~h}$ & 8 and $12 \mathrm{~h}$ & 12 and $24 \mathrm{~h}$ & 24 and $48 \mathrm{~h}$ & 48 and $72 \mathrm{~h}$ & \\
\hline Base varnish (no $\mathrm{F}^{-}$or $\mathrm{CaGP}$ ) & $0.55( \pm 0.05)$ & $0.46( \pm 0.02)$ & $0.35( \pm 0.04)$ & $0.28( \pm 0.06)$ & $0.24( \pm 0.04)$ & $1.98( \pm 0.18)^{a}$ \\
\hline Duraphat $^{\circledR}(2.26 \% \mathrm{~F})$ & $3.68( \pm 0.62)$ & $1.77( \pm 0.27)$ & $6.06( \pm 0.86)$ & $23.63( \pm 3.15)$ & $27.99( \pm 4.82)$ & $64.16( \pm 8.11)^{b}$ \\
\hline Duofluorid $^{\circledast}(5.63 \% \mathrm{~F})$ & $90.56( \pm 15.89)$ & $21.37( \pm 4.08)$ & $18.24( \pm 2.75)$ & $38.98( \pm 2.26)$ & $39.22( \pm 2.60)$ & $204.14( \pm 23.4)^{c}$ \\
\hline $1 \% \mathrm{CaGP} / 5.63 \% \mathrm{~F}^{1}$ & $215.74( \pm 26.02)$ & $84.09( \pm 10.72)$ & $58.18( \pm 10.16)$ & $64.69( \pm 16.06)$ & $28.59( \pm 3.67)$ & $438.86( \pm 65.53)^{\mathrm{d}}$ \\
\hline $5 \% \mathrm{CaGP} / 5.63 \% \mathrm{~F}^{2}$ & $233.76( \pm 11.75)$ & $61.46( \pm 4.36)$ & $19.35( \pm 0.65)$ & $44.14( \pm 2.73)$ & $46.82( \pm 3.38)$ & $410.38( \pm 24.19)^{\mathrm{e}}$ \\
\hline Negative control (no varnish) & $0.39( \pm 0.01)$ & $0.19( \pm 0.02)$ & $0.05( \pm 0.00)$ & $0.07( \pm 0.01)$ & $0.07( \pm 0.02)$ & $0.85( \pm 0.12)^{a}$ \\
\hline
\end{tabular}

aifferent letters mean statistical differences between the varnishes.

1 Experimental varnish 1.

2 Experimental varnish 2.

The analysis of the effect of the varnishes on enamel demineralization, showed that Duraphat ${ }^{\circledR}$, Duofluorid $^{\circledR}$ and experimental varnish 2 significantly reduced enamel demineralization compared to the negative control and base varnish groups $(\mathrm{p}<0.05$, Table 2). The experimental varnish 1 , however, showed similar results to Duofluorid ${ }^{\circledR}$ and experimental varnish 2, but also similar to the negative control.

\section{Discussion}

Previous studies had shown positive effects of $\mathrm{CaGP}$ in $\mathrm{F}$ dentifrices against dental caries in vitro and in vivo. ${ }^{5,6,7,21}$ In the present study, we added CaGP to $\mathrm{F}$ varnish, at concentrations of $1 \%$ and $5 \%$, with the aim of measuring the amount of $F$ released from these varnishes and their effect on in vitro demineralization. The concentrations of CaGP were chosen based on the results of previous studies testing CaGP in F dentifrice. ${ }^{7,21}$ The protective effect of $\mathrm{F}$ varnish is related to the formation of a $\mathrm{CaF}_{2}$-like layer on the enamel surface. ${ }^{22}$ We therefore speculated that the addition of CaGP would increase the amount of $F$ released from

Table 2. Mean $( \pm S D)$ of the percentage of the surface hardness change (\%SHC).

\begin{tabular}{|c|c|}
\hline Varnish & Mean $\%$ SHC $( \pm S D)$ \\
\hline Base varnish (no $\mathrm{F}^{-}$or $\mathrm{CaGP}$ ) & $-49.2( \pm 5.1)^{a}$ \\
\hline Duraphat $^{\circledR}(2.26 \% \mathrm{~F})$ & $-14.1( \pm 7.5)^{b}$ \\
\hline Duofluorid $^{\circledR}(5.63 \%$ F) & $-21.9( \pm 8.2)^{b, c}$ \\
\hline $1 \% \mathrm{CaGP} / 5.63 \% \mathrm{~F}^{1}$ & $-29.6( \pm 7.1)^{c, d}$ \\
\hline $5 \% \mathrm{CaGP} / 5.63 \% \mathrm{~F}^{2}$ & $-23.1( \pm 4.1)^{b, c}$ \\
\hline Negative Control (no varnish) & $-36.1( \pm 10.1)^{d}$ \\
\hline
\end{tabular}

the varnish and, consequently, enhance $\mathrm{CaF}_{2}$ formation and the protective effect against demineralization.

The mechanism of action of CaGP on caries prevention is still not well defined, but CaGP has been shown to protect enamel from cariogenic demineralization, ${ }^{5,6,7}$ probably owing to its interaction with the tooth minera $l^{8}$ or its action on dental plaque (buffering effect). ${ }^{23,24}$ In addition, CaGP and F have a synergic effect, promoting greater protection for enamel. ${ }^{9}$ In this study, we measured the release of $\mathrm{F}$ from the experimental varnishes following immersion in DDW for up to 72 hours. Other studies have reported such analyses, ${ }^{25,26}$ where F release was observed for periods of up to 20 weeks and over. Since, clinically, $F$ varnish only remains in contact with enamel for a few hours, we decided to study clinically relevant periods of time, with intervals of 1,8 and 12 hours. We did, however, include other time-points $(24,48$ and $72 \mathrm{~h}$ ) to determine whether F varnish could release $\mathrm{F}$ for longer periods.

In general, we observed that the highest $F$ release occurred during the first $8 \mathrm{~h}$ after application, and the amount of $F$ released from varnishes containing CaGP was significantly greater than that from the commercial F varnishes. After the first 8-h period, the amount of $F$ released from these varnishes substantially decreased. From these results, and taking other studies of the protective effect of $\mathrm{F}$ varnish against demineralization into consideration, ${ }^{25,26}$ a 6-hour exposure to $\mathrm{F}$ varnish seemed reasonable for the second stage of this study.

Considering both stages of the present study together, it is striking that the varnish with the lowest F release $\left(\right.$ Duraphat $\left.^{\circledR}\right)$ was the one that exhibited the 
greatest preventive effect against demineralization. This was unforeseen, as one would expect that greater F release would generate more $\mathrm{CaF}_{2}$-like material, which would, in turn, lead to a greater preventive effect. Greater F release, however, was observed from the experimental varnishes.

The greater amounts of $F$ released from the experimental varnishes could be either a result of their higher $\mathrm{F}$ concentration $(60 \%$ greater than that of Duraphat $\left.{ }^{\circledR}\right)$ or of their composition and viscosity. Duraphat ${ }^{\circledR}$ was found to be more viscous than Duofluorid ${ }^{\circledR}$ and the two experimental varnishes, so the latter varnishes could be spread over a larger area of the acrylic blocks. This increased their surface area in contact with the surrounding water and possibly led to greater release of $\mathrm{F}$. The experimental varnishes had the same F content as Duofluorid ${ }^{\circledR}$, so these varnishes might have been expected to release similar amounts of $F$ whereas, in fact, the experimental varnishes released significantly greater amounts of $\mathrm{F}$ than Duofluorid ${ }^{\circledR}$. This suggests that the mechanism involved in $\mathrm{F}$ release is probably related to the presence of CaGP. Furthermore, it might be that there is a saturation effect of the CaGP, since the varnish containing 5\% $\mathrm{CaGP}$ released less $\mathrm{F}$ than the one containing $1 \% \mathrm{CaGP}$.

Even though the experimental varnishes released significantly greater amounts of $\mathrm{F}$ than the other varnishes, this did not increase their preventive effect in the present experimental model. Therefore, we can hypothesize that a high $\mathrm{F}$ release does not indicate high cariostatic effect of these varnishes. The primary action of $\mathrm{F}$ in caries prevention, however, is more closely related to its presence in the fluid phases of the oral cavity, where F must be constantly present at low concentrations ${ }^{(4)}$. So, although greater amounts of $F$ are released by the experimental varnishes, this

\section{References}

1. Fejerskov O. Changing paradigms in concepts on dental caries: consequences for oral health care. Caries Res. 2004 May-Jun;38(3):182-91. PubMed PMID: 15153687.

2. Kidd EA, Fejerskov O. What constitutes dental caries? Histopathology of carious enamel and dentin related to the action of cariogenic biofilms. J Dent Res. 2004;83 Spec No C:C35-8. PubMed PMID: 15286119. does not necessarily imply a greater formation of $\mathrm{CaF}_{2}-$ like structures on enamel. Moreover, the increased amount of $F$ released from the experimental varnishes will probably have no significant preventive impact on tooth demineralization. A previous study showed that the preventive action of $\mathrm{F}$ varnish is limited to the area to which varnish has been applied. ${ }^{27}$ So the dynamic of ionic changes between varnish/water (or varnish/saliva) is probably different to that between varnish/enamel. In any case, further experiments are necessary to actually identify the mechanism of the experimental varnishes and to explore why the varnishes with lower F concentrations and later $\mathrm{F}$ release apparently promoted greater enamel protection. Although these questions need to be further investigated, it may be speculated that F can bind either loosely or firmly to the enamel surface, ${ }^{22,27}$ and the $\mathrm{CaF}_{2}$ layer will probably be more stable in situ. ${ }^{28}$

\section{Conclusion}

The present study shows that (1) the addition of CaGP to F varnishes significantly increased F release, but (2) these varnishes did not have a greater preventive effect against in vitro enamel demineralization using the present experimental model.

\section{Acknowledgements}

The authors thank the Coordenação de Aperfeiçoamento de Pessoal de Nível Superior (CAPES; www.capes.gov.br) and the Conselho Nacional de Desenvolvimento Científico e Tecnológico (CNPq; www.cnpq.br) for financial support. The authors would also like to express their gratitude to the post-graduates and professors at the Pediatric Dentistry Department (Faculdade de Odontologia - Universidade de São Paulo - FOUSP) for their valuable comments and discussions.

3. Marthaler T. Changes in dental caries 1953-2003. Caries Res. 2004 May-Jun;38(3):173-81. PubMed PMID: 15153686.

4. Buzalaf MA, Pessan JP, Honório HM, ten Cate JM. Mechanisms of action of fluoride for caries control. Monogr Oral Sci. 2011;22:97-114. PubMed PMID: 21701194.

5. Grenby T. Trials of 3 organic phosphorus-containing compounds as protective agents against dental caries in rats. J Dent Res. 1973 May-Jun;52(3):454-61. PubMed PMID: 4521636. 
6. Pianotti R, Ambrozaitis J, McNamara T. Cariostatic activity of calcium glycerophosphate in hamsters: topical vs dietary administration. J Dent Res. 1976 Nov-Dec;55(6):1092-6. PubMed PMID: 1069757.

7. Mainwaring P, Naylor M. A four-year clinical study to determine the caries-inhibiting effect of calcium glycerophosphate and sodium fluoride in calcium carbonate base dentifrices containing sodium monofluorophosphate. Caries Res. 1983;17(3):267-76. PubMed PMID: 6342787.

8. Grenby TH, Bull JM. Use of high-performance liquid chromatography techniques to study the protection of hydroxylapatite by fluoride and glycerophosphate against demineralization in vitro. Caries Res. 1980;14(4):221-32. PubMed PMID: 6929734.

9. Grenby TH, Bull JM. Chemical studies of the protective action of phosphate compounds against the demineralization of human dental enamel in vitro. Caries Res. 1980;14(4):210-20. PubMed PMID: 6929733.

10. Duke S, Rees D, Forward G. Increased plaque calcium and phosphorus concentrations after using a calcium carbonate toothpaste containing calcium glycerophosphate and sodium monofluorophosphate. Pilot study. Caries Res. 1979;13(1):57-9. PubMed PMID: 283888.

11. Tenuta LM, Cenci MS, Cury AA, Pereira-Cenci T, Tabchoury $\mathrm{CP}$, Moi GP, et al. Effect of a calcium glycerophosphate fluoride dentifrice formulation on enamel demineralization in situ. Am J Dent. 2009 Oct;22(5):278-82. PubMed PMID: 20225470.

12. Marinho V, Higgins J, LoganS, Sheiham A. Fluoride varnishes for preventing dental caries in children and adolescents. Cochrane Database Syst Rev. 2002 (3):CD002279. PubMed PMID: 12137653.

13. Petersson L. On topical application of fluorides and its inhibiting effect on caries. Odontol Revy Suppl. 1975;34:1-36. PubMed PMID: 830179.

14. Ogaard B. CaF(2) formation: cariostatic properties and factors of enhancing the effect. Caries Res. 2001;35 Suppl 1:40-4. PubMed PMID: 11359057.

15. Ogaard B, Rölla G, Helgeland K. Fluoride retention in sound and demineralized enamel in vivo after treatment with a fluoride varnish (Duraphat). Scand J Dent Res. 1984 Jun;92(3):190-7. PubMed PMID: 6589734.

16. Beltrán-Aguilar E, Goldstein J, Lockwood S. Fluoride varnishes. A review of their clinical use, cariostatic mechanism, efficacy and safety. J Am Dent Assoc. 2000 May;131(5):589-96. PubMed PMID: 10832252.
17. Clark DC. A review on fluoride varnishes: an alternative topical fluoride treatment. Community Dent Oral Epidemiol. 1982 Jun;10(3):117-23. PubMed PMID: 6955115.

18. Petersson LG, Twetman S, Dahlgren H, Norlund A, Holm AK, Nordenram G, et al. Professional fluoride varnish treatment for caries control: a systematic review of clinical trials. Acta Odontol Scand. 2004 Jun;62(3):170-6. PubMed PMID: 15370638.

19. Carvalho DM, Salazar M, Oliveira BH, Coutinho ES. Fluoride varnishes and decrease in caries incidence in preschool children: a systematic review. Rev Bras Epidemiol. 2010 Mar;13(1):139-49. PubMed PMID: 20683562.

20. Magalhães AC, Comar LP, Rios D, Delbem AC, Buzalaf MA. Effect of a $4 \%$ titanium tetrafluoride (TiF4) varnish on demineralisation and remineralisation of bovine enamel in vitro. J Dent. 2008 Feb;36(2):158-62. PubMed PMID: 18187248.

21. Naylor M, Glass R. A 3-year clinical trial of calcium carbonate dentifrice containing calcium glycerophosphate and sodium monofluorophosphate. Caries Res. 1979;13(1):39-46. PubMed PMID: 369697.

22. Attin T, Grieme R, Paqué F, Hannig C, Buchalla W, Attin $R$. Enamel fluoride uptake of a novel water-based fluoride varnish. Arch Oral Biol. 2005 Mar;50(3):317-22. PubMed PMID: 15740710.

23. Lynch R. Calcium glycerophosphate and caries: a review of the literature. Int Dent J. 2004;54(5 Suppl 1):310-4. PubMed PMID: 15509082.

24. Lynch R, ten Cate J. Effect of calcium glycerophosphate on demineralization in an in vitro biofilm model. Caries Res. 2006;40(2):142-7. PubMed PMID: 16508272.

25. Castillo J, Milgrom P, Kharasch E, Izutsu K, Fey M. Evaluation of fluoride release from commercially available fluoride varnishes. J Am Dent Assoc. 2001 Oct;132(10):1389-92; quiz 459-60. PubMed PMID: 11680353.

26. Castillo J, Milgrom P. Fluoride release from varnishes in two in vitro protocols. J Am Dent Assoc. 2004 Dec;135(12):1696-9. PubMed PMID: 15646602.

27. Attin T, Lennon A, Yakin M, Becker K, Buchalla W, Attin $\mathrm{R}$, et al. Deposition of fluoride on enamel surfaces released from varnishes is limited to vicinity of fluoridation site. Clin Oral Investig. 2007 Mar;11(1):83-8. PubMed PMID: 17043869.

28. Ganss C, Schlueter N, Klimek J. Retention of $\mathrm{KOH}$-soluble fluoride on enamel and dentine under erosive conditions--A comparison of in vitro and in situ results. Arch Oral Biol. 2007 Jan;52(1):9-14. PubMed PMID: 17049481. 


\section{Erratum}

In the article "Fluoride varnishes with calcium glycerophosphate: fluoride release and effect on in vitro enamel demineralization" published in the journal Brazilian Oral Research, volume 29, on page 1, for:

“Universidade de São Paulo - USP Bauru, School of Dentistry, Department of Pediatric Dentistry, Orthodontics and Community Health, Bauru, SP, Brazil."

read:

“Universidade de São Paulo - USP, Bauru School of Dentistry, Department of Pediatric Dentistry, Orthodontics and Community Health, Bauru, SP, Brazil." 